\title{
Administration of Ecclesiastical Temporal Goods in the Light of the Instructions of the Polish Episcopal Conference of 2015
}

\begin{abstract}
The mission of the Church is evangelisation and not acquisition of capital. It is good if the Church has sufficient financial means necessary to fulfil its mission. The Catholic Church has the inherent right, independently of any secular power, to acquire, retain, administer and alienate temporal goods, in pursuit of its proper objectives (can. 1254 of the Code of Canon Law). In order to fulfil its mission in the world, the Church needs to be supported by appropriate material goods and the freedom to administer them. The Code of Canon Law of 1983 introduced a new regulation regarding ecclesiastical property, so as to make sure that the Church could better suit the concept of a "poor Church" that, being in the need of economic resources to achieve its goals, focuses on the instrumental task of such resources: so that the faithful fulfilled their duty in the form of helping in maintaining the Church and its works as part of their fundamental rights and obligations related to the temporal goods; so that spiritual goal of ecclesiastical offices was emphasised and the revenues received were justly distributed. The Polish Episcopal Conference on 25 August 2015 approved the Instruction on the Administration of Ecclesiastical Temporal Goods. In the present article four points will be discussed: The right of the Church to the acquisition, holding and alienating of temporal goods; the Instruction of the Polish Episcopal Conference on the acquisition of temporal goods; the Instruction of the Polish Episcopal Conference on the administration of temporal goods and contracts; the Remuneration for priests.
\end{abstract}

\section{Keywords}

Administration of Ecclesiastical Temporal Goods, Canon Law, Episcopal Conference, Instructions of the Polish Episcopal Conference. 
In order to fulfil its mission in the world, the Church needs to be supported by appropriate material goods and the freedom to administer them. The Code of Canon Law of 1983 introduced a new regulation regarding ecclesiastical property, so as to make sure that the Church could better suit the concept of a "poor Church" that, being in the need of economic resources to achieve its goals, focuses on the instrumental task of such resources: so that the faithful fulfilled their duty in the form of helping in maintaining the Church and its works as part of their fundamental rights and obligations related to the temporal goods; so that spiritual goal of ecclesiastical offices was emphasised and the revenues received were justly distributed. On the other hand, the Code does not give the economical affairs any crucial importance but it leaves a wide field of application for the subordinate law. ${ }^{1}$ Hence, at a meeting of the diocesan bishops in Częstochowa on 25 August 2015, the Polish Episcopal Conference approved the Instruction on the Administration of Ecclesiastical Temporal Goods [hereinafter: Instruction]. ${ }^{2}$

\section{The right of the Church to the acquisition, holding and alienating of temporal goods}

In accordance with section 1254 of the Code of Canon Law: "The Catholic Church has the inherent right, independently of any secular power, to acquire, retain, administer and alienate temporal goods, in pursuit of its proper objectives". According to the legislative body, these objectives include the organisation of the worship of God, provision of decent maintenance to the clergy and other church workers and carrying out works of the apostolate and charity, especially for the poor.

${ }^{1}$ Cf. M. López Alarcón, De los bienes temporales de la Iglesia, in: eds. A. Marzoa, J. Miras, R. Rodriguéz-Ocaña, Comentario exegético al Código de Derecho Canónico, vol. IV/1, Pamplona 1997, pp. 25-40. G. Incitti, La Chiesa particolare, en: Corso istituzionale di Diritto Canonico, Milano 2005; J. Goti Ordeñana, Financiación de la Iglesia, "Revista Española de Derecho Canónico" 58 (2001), pp. 699-748; V. De Paolis, I beni temporali della Chiesa, Bologna 1995; F. R., Martínez Aguilar, Las normas sobre la administración económica en las Iglesias particulares. En especial su aplicación en el derecho particular del cono sur latinoamericano, Montevideo 1998; J. P. Schouppe, Elementi di Diritto Patrimoniale Canonico, Milano 1997.

${ }^{2}$ Polish Episcopal Conference, Instruction on the Administration of Ecclesiastical Temporal Goods, in: http://episkopat.pl/dokumenty/6918.1,Instrukcja_KEP_w_sprawie_ zarzadzania_dobrami_doczesnymi_Kosciola.html (15.11.2015). 
The administration of Church goods belongs to the person who directly administers a juridical person; for example, it is the duty of the parish priest in case of a parish.

\section{Determination of concepts}

First of all, temporal goods of the Church include all material things (items, buildings, land), both movable and immovable, which are owned by the Church. These may also be rights with a monetary (economic) value, held by the Church towards things belonging to other people, such as the right to use property on the basis of acts, agreements or other titles. These may also be receivables or an entitlement to certain benefits from certain people. According to Can. $1257 \$ 1$, ecclesiastical property includes any temporal property owned by the universal Church or other public juridical persons in the Church. ${ }^{3}$

The Code does not make a precise division of material goods. Nevertheless, it can be done, citing Bączkowicz, who divides ecclesiastical property as follows:

- sensory or tangible goods (bona corporalia) include those that fall under the senses and occur in space, such as land, money, etc.; nonsensory or intangible goods (bona incorporalia) are those that do not fall under the senses but can be determined and comprehended by thought, and they possess material value, e.g. stocks, bonds, securities or easements;

- sensory goods can be divided into movable and immovable ones (bona mobilia vel immobilia), depending on whether they can be moved from place to place without damaging them or not;

- movable goods are changeable (bona fungibilia) if in trade, or in legal action, the parties are focused on the type and quantity of goods in terms of number, measurement or weight, so that they can be simply replaced, e.g. grains, money, wine; or unchangeable (bona infungibilia) when it comes to goods that are individually marked;

3 The Code of Canon Law does not provide a full list of juridical persons in the Church. The general principle regarding the legal personality in the Church is given in Can. $116 \$ 2$ : „Public juridical persons are given this personality either by the law itself or by a special decree of the competent authority expressly granting it". Notwithstanding the above rule, at times, the Code makes it clear that an individual acquires legal personality by the law itself. So it is, for instance, in the case of a seminary (Can. $238 \$ 1$ ) or a parish (Can. $515 \$ 3$ ). E. Sztafrowski, Podręcznik Prawa Kanonicznego, vol. 3, Warsaw 1986, p. 275. 
- goods can be consumable (bona primo usu consumptibilia) if one can benefit from them in accordance with their ordinary purpose and destination through consumption, eating them or disposing of them, such as food, fuel, post stamps, money, etc.; or inconsumable (bona non consumptiblia) if their normal use does not involve instant consumption of the substance, e.g. buildings or appliances;

- major and minor goods (res principales et accessoriae). A property is considered minor if it is legally connected with the major property in such a way that it cannot be separated from it without damage or making a significant change; it shares the fate of the major property. Minor goods include the so-called appurtenances, i.e. things that are not components of the major property but are destined to be continually used for its benefit, such as the church equipment, inventory or estates;

- sacred goods (res sacrae) are those goods that are earmarked for religious purposes through consecration or blessing, such as chalices, chasubles, etc.;

- valuable goods (res pretiosae) are things of artistic or historical value or made of expensive material, e.g. artistic furniture, old books, chalices, chasubles, paintings, etc. ${ }^{4}$

\section{Acquisition of goods}

According to Can. 1259: "The Church may acquire temporal goods in any way in which, by either natural or positive law, it is lawful for others to do this". Under the natural law, there are the following ways of acquisition of goods:

- appropriation (occupatio), or taking over things that belong to no one;

- transformation (specificatio), or reworking of a material to a new thing;

- accession (accessio), or acquisition of property by joining goods belonging to different owners;

- contract, or an agreement sufficient for the transfer of ownership according to the natural law, as far as the positive law does not provide for certain conditions;

- last will for the benefit of the Church (e.g. a testament). ${ }^{5}$

${ }^{4}$ F. Bączkowicz, Prawo kanoniczne. Podręcznik dla duchowieństwa, vol. II, Opole 1958, pp. 538-539.

${ }^{5}$ E. Sztafrowski, Podręcznik Prawa Kanonicznego, pp. 276-277. 
Pursuant to the civil positive law, there are the following methods of acquisition of material goods:

- various contracts, to which formalities and conditions are assigned under the civil law. The ecclesiastical law recognises these provisions unless they are contrary to the law of God or it is otherwise stated in the canon law;

- last will regulated by national standards, such as testaments, legacies or donations in the event of death;

- intestacy;

- acquisitive prescription and limitation, if not contrary to the ecclesiastical law. $^{6}$

\section{Instruction of the Polish Episcopal Conference on the acquisition of temporal goods}

Section two of the Instruction is devoted to the issue of acquisition of goods. There are the following principles that should be followed when acquiring such goods:

- The transfer of temporal goods to the benefit of the Church may be performed by any legal ways (Can. 1259). These include collects that occur during services, voluntary offerings accompanying the sacraments or pastoral ministry, offerings in response to requests, collection of alms, offerings by pious autonomous or non-autonomous funds, fees for issuing administrative acts, donations to a religious cult, donations to the charity and care activities of the Church, offerings in the form of fruits of the earth to the seminary or convent, transfer of $1 \%$ of the tax to a Church institution with the status of a public benefit organisation as well as inter vivos and in mortis causa legal activities. ${ }^{7}$

- Offerings (oblationes) given on the occasion of the sacraments and sacramentals as well as other liturgical celebrations are a gift, through which the faithful contribute to the conduct of pastoral activity and help in the maintenance of the clergy (cf. Can. 946 of the Code of Canon Law). However, the administration of the sacraments, sacramentals

6 E. Sztafrowski, Podręcznik Prawa Kanonicznego, pp. 276-277.

7 Instruction, 2, 2. 
and any other liturgical celebrations cannot be dependent on donation (cf. Can. $945 \$ 2$ and Can. 1181 of the Code of Canon Law). Therefore, no rates or "price lists" should be established. It is also recalled that "for the administration of the sacraments, the minister may not ask for anything beyond the offerings, which are determined by the competent authority, and the needy must not be deprived of the help of the sacraments by reason of poverty" (Can. 848 of the Code of Canon Law). ${ }^{8}$

- Offerings (donations) given to a public juridical person (e.g. a parish) cannot be rejected if there is no just reason and, in matters of greater importance, only with the consent of the diocesan Bishop. A consent of the diocesan Bishop following the procedure set out in Can. 12911294 of the Code of Canon Law is required for the acceptance of offerings (donations), to which some obligations determining the use (e.g. encumbered by a mortgage, pledge, easement or a lease) or conditions are attached (cf. Can. $1267 \$ 2$ of the Code of Canon Law). In the case of a donation encumbered by a condition, failure to meet the condition specified in the donation agreement results in the invalidity of the legal measure (cf. Art. 890 of the Polish Civil Code). A just reason may relate to a decent source of the goods, the good faith of the donor, the nature of the property, its external appearance or destination, etc. Therefore, before accepting the goods, one should find out what is the subject of the offering (donation), is it moral and fair, will it not be a burden for the ecclesiastical public juridical person and whether it has any concealed obligations attached. The acceptance or rejection of such an offering (donation) requires particular prudence. ${ }^{9}$

- Offerings (donations) given by the faithful for a particular purpose may be used only for that purpose (cf. Can. $1267 \$ 3$ of the Code of Canon Law). No one is permitted to change the will of the donor. In case of doubts concerning the purpose of the donation, the donor should be contacted. However, if there is no such possibility, reference should be made to the Ordinary who is the executor of all pious dispositions, whether made via a testament or inter vivos, in accordance with Can. $1301 \$ 1$ of the Code of Canon Law. To a donation agreement, the provisions of the civil law

\footnotetext{
${ }^{8}$ Instruction, 2, 5.

9 Instruction, 2, 9.
} 
are applied to the same effect, unless they are contrary to the law of God or it is otherwise stated in the canon law (cf. Can. 1290). ${ }^{10}$

- Acquisition and disposal of real property must be performed by a notarial deed or otherwise, as provided for in the Polish law (cf. Art. 158 of the Polish Civil Code) ${ }^{11}$

- Every year, in each diocese there should be a legal act announced concerning financial benefits which should contain inter alia a list of collections, donated on plates or in boxes, their purpose and dates. ${ }^{12}$

- As a matter of principle, fundraising by means if using collection plates or collection boxes, counting them and bookkeeping should not be performed by priests. ${ }^{13}$

\section{Instruction of the Polish Episcopal Conference on the administration of temporal goods and contracts}

Regarding the administration of temporal goods, the Instruction refers first of all to the regulations of the Code. The following issues should be noted:

Therefore, the administrators of ecclesiastical goods should in particular ${ }^{14}$ :

- be vigilant that no goods placed in their care in any way perish or suffer damage; to this end they are, to the extent necessary, to arrange property insurance contracts and third party liability insurance contracts;

- ensure that the ownership of ecclesiastical goods is safeguarded in ways which are valid in the Polish law;

- observe the provisions of both canon and Polish law, and the stipulations of the founder or donor or lawful authority; they are to take special care that damage will not be suffered by the Church through the nonobservance of the civil law;

- ensure that the factual status of property ownership is compliant with the legal status (church buildings should be plotted on the cadastral map, entered into the register of lands and buildings as well as shown in the

\footnotetext{
${ }^{10}$ Instruction, 2.10.

${ }^{11}$ Instruction, 2, 12.

${ }^{12}$ Instruction, 2, 16.

${ }^{13}$ Instruction, 2, 17.

14 Instruction, 3, 3.
} 
land and mortgage register; these documents should also contain notes regarding any changes in the factual status);

- seek accurately, and at the proper time, the income and produce of the goods (rents, fees, interest, etc.), hold them in a bank account and expend them in accordance with the wishes of the lawful norms;

- at the proper time pay taxes and fees for utilities (water, electricity, heating, refuse collection, etc.);

- at the proper time pay other obligations (remuneration for provided services, credit or loan instalments, etc.);

- for the benefit of ecclesiastical juridical person, deposit money remaining after payment of expenses, upon approval of the diocesan bishop. Without prior written approval of the diocesan bishop, it is forbidden to deposit funds in high risk financial instruments (e.g. stock, shares in investment funds);

- keep accurate records of income and expenditure;

- draw up clear and accurate inventory of immovable and movable goods;

- keep records of buildings and perform timely inspections of all technical installations in those buildings. Reports on those inspections should be signed by licensed surveyors;

- at the end of each year, draw up a report on the administration of goods and submit it for the approval of the diocesan bishop;

- properly arrange and store in an appropriate archive, as well as safeguard documents and evidence, upon which the property rights of an ecclesiastical juridical person are based; their true copies should be submitted to the diocesan curia.

The Instruction recommends "that at the level of a diocese, stricte pastoral activity should be separated from other activities, especially from business activity, which should be separated in terms of organisation and bookkeeping. For this purpose, there should be a special institution collecting goods and offerings intended as remuneration for priests who serve God for the good of a diocese, in accordance with Can. $281 \$ 1$ (cf. Can. $1274 \$ 1$ ). It is also recommended that the ownership right to agricultural properties (former benefices recovered after 1989 by dioceses and parishes) should be transferred to the aforementioned institution, if it is economically justifiable. Otherwise, the administration of those properties should be granted to this institution. The activity of such administrative institution should be subjected to external audit every year. It is also recommend that a common fund should be created, from 
which the bishop could remunerate other persons serving the Church, help various needs of a diocese and from which also richer dioceses could help the poorer ones (cf. can. $1274 \$ 3$ )". ${ }^{15}$

Each commercial lease, lease, lending of ecclesiastical property should be performed in written form, in compliance with the provisions of the canon law, in particular Can. 1297 and Can. 1298 of the Code of Canon Law and the provisions of Polish laws. If indicated contracts are to be binding for more than 2 years, a prior approval of the diocesan bishop will be required. ${ }^{16}$

According to the decision of the Polish Episcopal Conference of $18^{\text {th }}$ $19^{\text {th }}$ October 2006 approved by the Holy See,${ }^{17}$ the requirement of obtaining approval of competent authorities (the diocesan bishop, the college of consultors, the finance committee and interested persons - cf. Can $1291 \$ 1$ of the Code of Canon Law) occurs in the event of alienation of property owned by an ecclesiastical juridical person with the value between EUR 100,000 and EUR 1 Milion. ${ }^{18}$

On the goods offered by the faithful to the Church, the administrators should provide the faithful with relevant reports, according to standards determined by the diocesan bishop (cf. Can. $1287 \$ 2$ of the Code of Canon Law). It is suggested that in parishes, the faithful should be informed on an ongoing basis (on the following Sunday) about the amounts obtained from collection plates and collection boxes intended for the parish purposes. It is recommended that an annual balance sheet should be drawn up. Such balance sheet should be made available to the faithful (e.g. in the parish bulletin, on the parish website) by the end of January of the year following the reporting year. The practice of presenting the aforementioned balance sheet during a service on the last day of a given calendar year is worth recommending. Such a balance sheet should be also drawn up by each diocese and made available to the faithful by the end of the first quarter of the year following the reporting year. "This is one of the methods to present the Church as economically reliable and awaken to the coresponsibility for its works". ${ }^{19}$

\footnotetext{
${ }^{15}$ Instruction, 3, 8.

${ }^{16}$ Cf. Instruction, 3, 17.

17 Dekret Kongregacji ds. Biskupów Prot. 901/84.

18 Cf. „Akta Konferencji Episkopatu Polski” 2007, no 13, pp. 32-33.

19 II Polski Synod Plenarny (1991-1999), Kościół wobec życia społeczno-gospodarczego, no. 56. Cf. Instruction, 3, 27.
} 
It is worthwhile to note Article 3.28 of the Instruction where we can read: "Pursuant to the provisions of Polish law referring to donations, in other events it is forbidden to publicly disclose personal details of donors. It is prohibited to read in church, post in cabinets, post on parish websites, etc. the amounts, surnames, names, addresses and other details of persons or institutions that gave, or did not give, offerings or donations."

Chapter Four of the Instruction refers to contracts. Relevant contracts (e.g. employment contracts, contracts for specific works, mandate contracts, fundraising contracts) should be signed, and employment records should be kept, according to the provisions of Polish law with and for all employees of ecclesiastical juridical persons and ecclesiastical organisational units, as well as with, and for persons providing any kind of services to them. ${ }^{20}$

\section{Remuneration for Priests}

The Polish remuneration system for priests is based on voluntary offerings, especially offerings during a service and iura stolae. However, the Instruction emphasises several issues in this regard: ${ }^{21}$

- Income of the priests - both in cash and in kind (accommodation, food, etc.) - and their obligations towards the parish and the diocese should be specified in detail in the subordinate law of a given diocese.

- The Ordinary is responsible for the determination of purposes, for which offerings from services celebrated twice, three times and common services will be given.

- In terms of social security, each priest is subject to the provisions of Polish law, therefore, he must apply for social insurance, pay relevant contributions and fill in relevant documents. In the case of priests, who entered into employment relationship, those obligations are imposed on their employers.

- Canon $281 \S 1$ of the Code of Canon Law assumes healthy differentiation of priests' remuneration (rejects the principle of extreme egalitarianism), by formulating a rule that remuneration should be determined in such a way so that priests could provide for the necessities of their life and

\footnotetext{
${ }^{20}$ Cf. Instruction, 4, 4.

${ }^{21}$ Cf. Instruction, 5, 2-8.
} 
for the just remuneration of those whose services they need. For the determination of priests' remuneration, the nature of their office and the conditions of time and place should be taken into account. It should be remembered that Can. $282 \$ 1$ of the Code of Canon Law (following a simple way of life and avoiding anything which smacks of worldliness) should be observed.

- Conditions that regulate the level of remuneration of priests who dedicate themselves to the ecclesiastical ministry should be inter alia as follows:

- the level of education - priests as persons with tertiary education should be remunerated at the level of the lay members of Christ's faithful, who graduated from a university, however in lower remuneration group; - the period of ecclesiastical ministry - the remuneration should be directly proportional to the period of ministry: the longer this period is, the higher the remuneration should be;

- position held (e.g. bishop, parish priest, vicar, employee of church administration) - the greater the responsibility, the higher the remuneration should be;

- life environment - the type of environment and costs of living in such an environment should be taken into account;

- the society's material status - the amount of remuneration is not absolute because it depends on the society's material status. The remuneration of priests should be below the national average salary. In their lifestyle, priests should be close to the average or rather the poorer family.

- The Church provides the priests with means to support themselves but at the same time encourages a voluntary poor and simple way of life. Goods which are over and above what is necessary (bona superflua) should be used by priests for the good of the Church and for charitable works. ${ }^{22}$

\section{Conclusion}

The mission of the Church is evangelisation and not the acquisition of capital. It is good if the Church has sufficient financial means necessary to fulfil its

${ }^{22}$ More on this subject: R. Kantor, Odpowiednie wynagrodzenie duchownych w Kodeksie Prawa Kanonicznego z 1983 r. Analiza kan. 281 \& 1, „Prawo Kanoniczne” 54 (2011), no. 3-4, pp. 191-222. 
mission. The $4^{\text {th }}$ Synod in force practically did not address the issue of diocesan structures connected with the administration of temporal goods. Therefore, there are no particular provisions referring to the institution of a diocesan financial administrator, administrative director or diocesan conservator. The postulate of the $4^{\text {th }}$ Synod about the establishment of a special working team composed of employees of the Diocesan Curia and parish priests in order to determine the funding issues of Tarnów Diocese has not been implemented. On the other hand, we have many decrees on property issues in Tarnów Diocese, e.g. a decree on annual financial statement (2001), regulations of the parish finance committee (2002), decree on conducting a census of all land properties and buildings owned by the parish as well as church institutions (2008), Pro memoria on church building, parish investments, repairs and protection of parish monuments (2010). The aforementioned particular regulations indicate that 29 years that have passed since the $4^{\text {th }}$ Synod of Tarnów Diocese are a long period, during which many changes occurred in economic structures of our country that are also reflected in the issue of temporal goods of the Tarnów Church.

Property issues of the Tarnów Church were regulated in detail in previous synods. The position of the diocesan employer has always been based on the voluntary nature of the offerings of the faithful, both in the case of investments and iura stolae fees. Voluntary offerings are still the basic source of Tarnów Diocese asset base. However, the method of obtaining offerings should be reformed and this has already been performed in other post-communist countries.

\section{Bibliography}

Bączkowicz F., Prawo kanoniczne. Podręcznik dla duchowieństwa, t. II, Opole 1958.

De Paolis V., I beni temporali della Chiesa, Bologna 1995.

Incitti G., La Chiesa particolare, en: Corso istituzionale di Diritto Canonico, Milano 2005. Goti Ordeñana, J., Financiación de la Iglesia, "Revista Española de Derecho Canónico" 58 (2001), p. 699-748.

Kantor R., Odpowiednie wynagrodzenie duchownych w Kodeksie Prawa Kanonicznego z 1983 r. Analiza kan. 281 \& 1, „Prawo Kanoniczne” 54 (2011) nr 3-4, s. 191-222.

Konferencja Episkopatu Polski, Instrukcja w sprawie zarządzania dobrami doczesnymi Kościoła, in: http://episkopat.pl/dokumenty/6918.1,Instrukcja_KEP_w_sprawie_ zarzadzania_dobrami_doczesnymi_Kosciola.html (15.11.2015). 
López Alarcón M., De los bienes temporales de la Iglesia, in: eds. A. Marzoa, J. Miras, R. Rodriguéz-Ocaña, Comentario exegético al Código de Derecho Canónico, vol. IV/1, Pamplona 1997, p. 25-40.

Martínez Aguilar F. R., Las normas sobre la administración económica en las Iglesias particulares. En especial su aplicación en el derecho particular del cono sur latinoamericano, Montevideo 1998.

Schouppe J. P., Elementi di Diritto Patrimoniale Canonico, Milano 1997.

Sztafrowski E., Podręcznik Prawa Kanonicznego, t. 3, Warszawa 1986. 